\title{
Pembuatan Alternator Axial Flux Coreless Dengan Menggunakan Magnet Permanen
}

\author{
Clarissa Amelia Sitorus dan Yono Hadi Pramono \\ Departemen Fisika, Fakultas Matematika dan Ilmu Pengetahuan Alam, Institut Teknologi Sepuluh Nopember (ITS) \\ e-mail: yonohadipramono@gmail.com
}

\begin{abstract}
Abstrak-Telah dilakukan penelitian pada alternator axial flux coreless dengan menggunakan magnet permanen dimana penelitian ini bertujuan menghitung efisiensi berdasarkan hasil perhitungan secara teoritis maupun secara percobaan. Rotor magnet permanen menggunakan 12 magnet neodymium dengan 6 koil sebagai stator. Generator aksial ini diputar dengan motor pada kecepatan berbeda $(360 ; 482 ; 482,7 ; 485,1 ; 485,3 ; 485,9)$. Dari hasil pengukuran didapatkan hasil pada 3 koil maupun 6 koil dapat menghasilkan tegangan yang sebanding dengan kecepatan putarnya. Untuk kecepatan terendah $360 \mathrm{rpm}$ didapatkan 5,8 Volt pada 3 koil sedangkan 13,8 Volt pada 6 koil dengan arus yang sama sebesar 2,5 Ampere. Perhitungan tegangan juga dilakukan secara teoritis berdasarkan parameter fisik dan studi literatur. Perbedaan hasil perhitungan dengan hasil pengukuran rata - rata $22 \%$. Perhitungan effisiensi generator dilakukan dengan membandingkan daya output generator dengan daya output motor penggerak. Hasil pada generator 3 koil memiliki effisiensi tertinggi $28,75 \%$ sedangkan 6 koil sebesar 62,083 \%. Dari penelitian ini didapatkan kesimpulan bahwa generator aksial magnet permanen akan memiliki efisiensi yang cukup tinggi dengan semakin banyak koil dan semakin cepat putarannya.
\end{abstract}

Kata Kunci- Effisiensi, Magnet Permanen, Rotor, RPM, Stator.

\section{PENDAHULUAN}

$\mathrm{E}$ NERGI memegang peranan penting dalam berbagai kehidupan manusia. Secara garis besar menurut sumbernya energi dibedakan menjadi dua yaitu sumber energi tidak dapat diperbaharui (Non - Renewable Energy) dan sumber energi dapat diperbaharui (Renewable Energy) [1]. Sumber energi tidak dapat diperbaharui merupakan sumber energi yang memiliki jumlah terbatas dengan contoh yang berasal dari fosil yang terbentuk dalam jutaan tahun lamanya sedangkan sumber energi dapat diperbaharui adalah sumber energi yang digunakan secara terus menerus tanpa dikhawatirkan habis dengan contoh solarcell, geothermal, energi angin. Penelitian ini menggunakan sejumlah magnet permanen dari bahan Neodymium yang disusun sedemikian rupa sehingga menghasilkan luaran tegangan 1 fasa. Mengapa dipilih magnet permanen, karena rangkaian akan lebih sederhana tanpa memerlukan catu daya tersendiri yang berfungsi untuk membangkitkan medan magnet induksi. Generator merupakan salah satu alat yang mengubah energi mekanik (gerak) menjadi energi listrik. Generator yang menghasilkan listrik bolak - balik (AC) disebut juga dengan alternator. Prinsip dasar alternator menggunakan hukum Faraday yang berbunyi "Apabila suatu batang penghantar digerakkan didalam suatu medan magnet yang mempunyai garis gaya magnet dari arah kutub utara ke arah kutub selatan, maka pada batang penghantar akan memotong garis - garis gaya magnet yang akan menimbulkan gaya gerak listrik (GGL) atau EMF (Electro Motive Force) [2]. Alternator terdiri dari 2 bagian besar yaitu stator dan rotor. Dimana pada stator terdapat kumparan - kumparan yang menghasilkan gaya gerak listrik (GGL) sedangkan pada rotor terdapat sebuah sumber medan magnetik. Untuk sumber medan magnetik dari magnet permanen, jenis magnet yang terbaik adalah jenis Besi Boron Neodymium (NdFeB) [3].

Induksi elektromagnetik yang terjadi pada generator mengacu pada hukum Faraday dan hukum Lenz. Sejalan dengan Faraday, menurut Lenz, arus induksi yang muncul akan berlawanan arah dengan arah perubahan fluks yang menyebabkan arus induksi mengalir. Dengan kata lain, arah induksi menghasilkan medan magnet yang melawan arah perubahan fluks magnet [4].
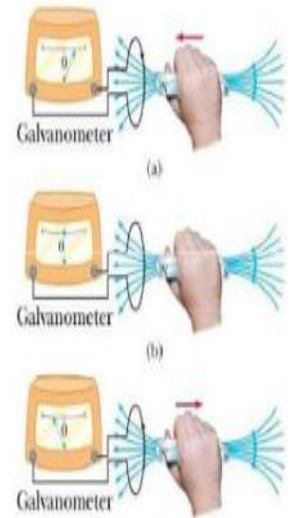

Gambar 1. Prinsip Hukum Lenz [4].

Generator fluks aksial memiliki struktur yang hampir sama dengan generator fluks radial. Secara umum persamaan diantara keduanya terletak pada komponen stator dan rotor sedangkan perbedaan diantara keduanya yaitu pada arah fluksnya dimana pada generator fluks radial, arah fluks magnet keluar kesegala arah sehingga bentuk tersebut tidak semua fluks tertangkap pada stator. sehingga hal ini menyebabkan sebagian fluks terbentuk akan terbuang dan menjadi rugi - rugi pada generator. Sedangkan pada generator fluks aksial, arah fluks magnet mengarah secara aksial sehingga kondisi ini membuat fluks tidak banyak terbuang dan membuat generator tersebut memiliki efisiensi yang lebih tinggi [5]. 
Induktor adalah komponen berupa kumparan kawat penghantar yang memiliki bahan inti berupa bahan elektrik. Induktor dapat menyimpan energi dalam bentuk medan magnetik. Pada Penelitian ini menggunakan kumparan dengan tipe lilitan berlapis inti udara (Multilayer Air Core Solenoid).

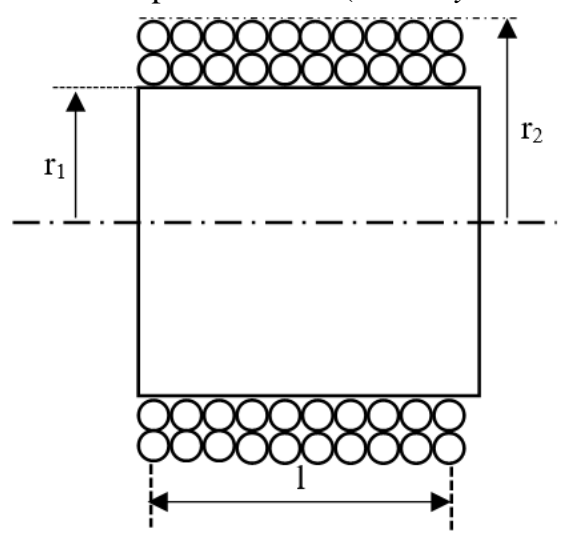

Gambar 2. Multilayer Air Core Solenoid [6]

Pada Gambar 2. diatas maka dari tabel diatas dapat dirumuskan sebagai berikut [6] :

$$
\mathrm{L}=\frac{31.6 r_{1}^{2} N^{2}}{6 r_{1}+9 i+10\left(r_{2}-r_{1}\right)}
$$

Untuk menghitung jumlah lilitan perlapisan maka dapat dilihat gambar dibawah ini [7]:

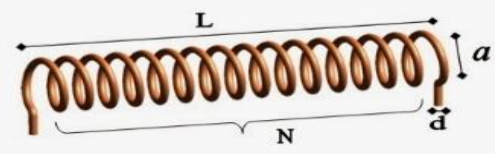

Gambar 3. Lilitan Kawat [7]

Pada Gambar 3. diatas maka dapat dihitung jumlah lilitan perlapisan adalah [8] :

$$
\mathrm{N}_{\mathrm{n}}=\frac{L}{\mathrm{~d}}
$$

Untuk menghitung panjang kawat berlapis, yaitu [8] :

$$
1_{\mathrm{n}}=2 \pi \mathrm{aN} \mathrm{N}_{\mathrm{n}}
$$

Untuk menghitung hambatan induktor [8] :

$$
\mathrm{R}=\rho \frac{L}{A}
$$

Perbandingan kekuatan magnet neodymium dapat dilihat pada gambar dibawah:

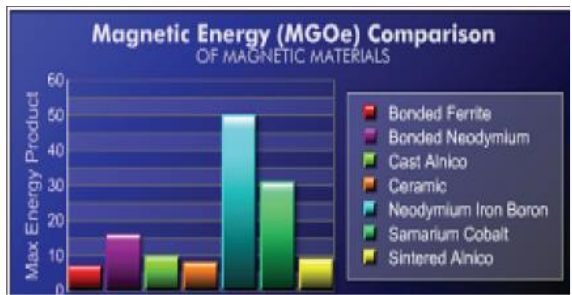

Gambar 4. Perbandingan Kekuatan Magnet Neodymium [9]

Dinamometer biasanya digunakan untuk mengukur torsi sebuah mesin. Prinsip kerja dari Gambar 5. adalah rotor dihubungkan secara elektromagnetik dan bergesekan mekanis terhadap stator yang ditumpu oleh bidang datar yang mempunyai gesekan kecil sehingga torsi yang dihasilkan stator maka rotor yang berputar dapat diukur dengan cara menyeimbangkan stator dengan pemberat [10].
Torsi mekanis yang dihasilkan mesin adalah [10]:

$$
\tau=\mathrm{W} \text { x r }
$$

Dengan : $\tau=$ torsi $(\mathrm{Nm}), \mathrm{W}=$ berat load cell $($ Newton $) \mathrm{R}=$ jarak poros ke load cell (meter)

Adapun daya mekanis $\left(\mathrm{P}_{\text {output }}\right)$ yang dihasilkan oleh mesin atau diserap oleh dinamometer adalah [10] :

$$
\mathrm{P}=2 \pi \mathrm{v} \tau
$$

Dengan : $\mathrm{P}=$ watt, $\mathrm{v}=$ kecepatan putar $(\mathrm{rpm}), \tau=$ torsi

Sedangkan daya elektrik ysng diserap oleh motor penggerak ( $\left.\mathrm{P}_{\text {input }}\right)$ adalah

$$
\mathrm{P}=\mathrm{V} \mathrm{I}
$$

Dengan : $\mathrm{P}=$ watt, $\mathrm{V}=$ tegangan (volt), $\mathrm{I}=$ arus (ampere)

Effisiensi yang dihasilkan oleh mesin adalah [10]:

$$
\eta=\frac{\text { Pout }}{\text { Pinput }} \times 100 \%
$$

Gambar 5. Prinsip Kerja Dinamometer [10]

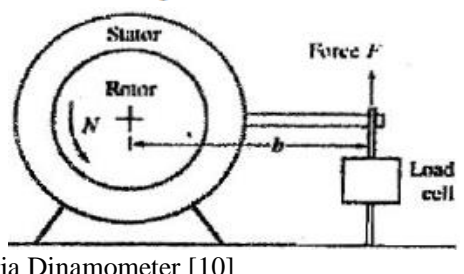

NdFeB dikenal sebagai magnet tanah jarang karena komposisi materialnya tersusun dari unsur - unsur tanah jarang. $\mathrm{NdFeB}$ memiliki sifat korosif dan energi produk yang maksimum [11].

\section{URAIAN PENELITIAN}

\section{A. Studi Literatur}

Studi literatur dilakukan untuk mendapatkan informasi yang lebih akurat dalam melaksanakan penelitian sehingga mempermudah penulis untuk melaksanakan kegiatan penelitian di lapangan. Sumber - sumber pustaka yang digunakan penulis dalam penelitian ini merupakan jurnal nasional dan internasional, buku teks, makalah dan dari internet.

\section{B. Perancangan Alat}

Alternator axial flux coreless dengan menggunakan magnet permanen yang dirancang dalam penelitian ini terdiri atas 6 koil yang dihubungkan secara seri yang diletakkan pada piringan stator, magnet permanen neodymium 12 buah pada piringan rotor, satu buah flywheel dan satu buah AC motor 200 watt sebagai penggerak. Adapun spesifikasi lengkap dari alternator ini dapat dilihat pada tabel 1. dibawah ini :

Tabel 1.

Spefisikasi Alternator yang dibuat

\begin{tabular}{cc}
\hline \hline Parameter & Nilai \\
\hline Arus & 3 Ampere \\
Voltase & 16 Volt \\
Daya & 48 watt \\
Jumlah Magnet & 12 buah \\
Jumlah Koil & 6 pasang \\
Jumlah lilitan & 130 \\
Diameter kawat & $1,6 \mathrm{~mm}$ \\
Diameter Rotor & $0,35 \mathrm{~m}$ \\
Diameter Stator & $0,35 \mathrm{~m}$ \\
Jari - jari dalam solenoida & $0,05 \mathrm{~m}$ \\
Jari - jari luar solenoida & $0,07 \mathrm{~m}$ \\
\hline \hline
\end{tabular}




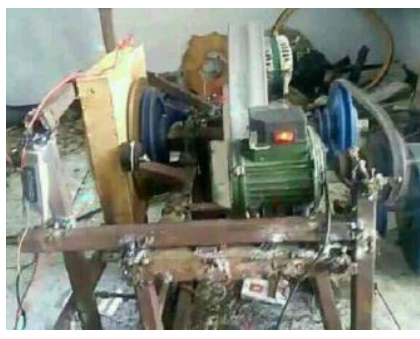

Gambar 6. Gambaran Rancangan Alat Alternator.

\section{Pembuatan Sistem Pemutar}

Pembuatan sistem pemutar rotor 12 magnet permanen dilakukan dengan langkah - langkah sebagai berikut pertama menentukan jumlah magnet pada piringan rotor. Pada penelitian ini menggunakan 12 buah magnet permanen yang disusun secara simetris dengan kutub yang berbeda antara magnet satu dengan magnet yang disebelahnya. Kedua adalah menentukan jenis magnet dimana magnet yang digunakan pada penelitian ini adalah jenis magnet $\mathrm{NdFeB}$ dengan ukuran 0,05 $\mathrm{m} \times 0,05 \mathrm{~m}$ berbentuk persegi. Pemilihan magnet dengan jenis ini dikarenakan magnet jenis neodymium ini lebih kuat dari magnet baja biasa dan cukup mudah didapatkan dipasaran. Ketiga adalah menentukan jarak antar magnet dengan sudut magnet terhadap pusat piringan rotor. Dengan jumlah 12 magnet maka tiap magnet diletakkan pada tiap sudut 36 derajat. Keempat adalah menentukan berat piringan rotor agar rotor dapat dengan mudah diputar pada kecepatan rendah. Bahan yang dipilih adalah bahan resin dengan diameter 0,35 $\mathrm{m}$. Diameter piringan rotor menyesuaikan dengan diameter piringan stator agar posisi tiap magnet tepar berada diatas kumparan stator [12].

\section{Pembuatan 6 Koil}

Dalam pembuatannya mula - mula diperlukan pola untuk membentuk gulungan (koil) dengan bentuk yang telah disesuaikan, kemudian proses pengulungan kawat seperti terlihat pada Gambar 7. dibawah ini

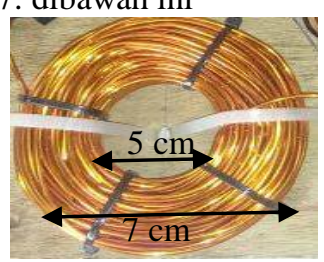

Gambar 7. Proses Pengulungan Kawat

Kumparan yang digulung memiliki diameter dalam sebesar $5 \mathrm{~cm}$ dan diameter luar $7 \mathrm{~cm}$ dengan banyak lilitan sebesar 300 lilitan seperti terlihat pada Gambar 7 diatas. Setelah proses penggulungan kawat semua selesai maka dilakukan perangkaian antara gulungan kawat (kumparan) dengan hubungan rangkaian seri. Ujung - ujung kawat satu kumparan disolder dengan kumparan lain membentuk rangkaian kumparan seri. Langkah selanjutnya adalah melakukan pengecoran kumparan yang telah disusun tadi menggunakan resin yang sebelumnya dilapisi oleh serat fiber untuk memperkuat keeping stator. Lama proses pengeringan dari resin membutuhkan waktu minimal 4 jam, kemudian didiamkan selama satu hari supaya resinnya benar - benar kering sehingga pada saat pelepasan dari cetakan tidak mengalami kerusakan. Hasilnya dapat dilihat pada Gambar 8 dibawah

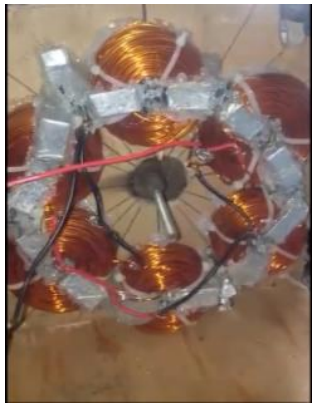

Gambar 8. Pembuatan 6 koil

Selanjutnya dilakukan pemeriksaan sambungan antar kumparan dengan menggunakan AVOmeter dengan mengukur tahanannya untuk memeriksa apakah gulungan sudah tersambung dengan baik atau belum. Setelah hasil pengukuran tahanan didapatkan hasil yang baik (tahanan kecil) maka kumparan siap dikopel dengan rotor.

\section{E. Pengujian Alternator}

Pengujian ini bertujuan untuk melihat hasil keluaran dari alternator serta faktor apa saja yang dapat mempengaruhi keluaran dari alternator. Alternator diukur keluaran tegangannya menggunakan AVOmeter dan keluaran dari alternator juga diuji kemampuannya dalam pengisian ACCU. Dan pengujian kecepatan putaran alternator dilakukan dengan mengukur kecepatan putar alternator (RPM) menggunakan tachometer seperti pada Gambar 9. Dibawah.

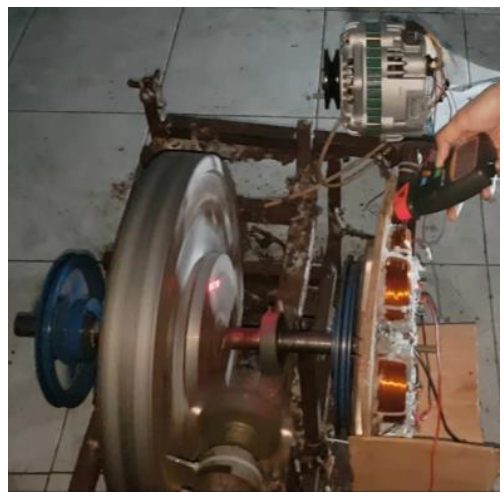

Gambar 9. Pengukuran kecepatan menggunakan tachometer

\section{F. Analisis Data}

Data yang didapat dari hasil pengujian untuk kemudian dianalisis dan dibandingkan dengan hasil perhitungan secara teoritis. Hasil pengukuran pada proses pengujian diantaranya berupa data tegangan keluaran alternator, arus dan kecepatan putar alternator. Perhitungan secara teoritis menggunakan paramater - parameter fisis alternator yang sudah diukur sebelumnya untuk kemudian dimasukkan pada rumus - rumus yang sesuai untuk menghasilkan perhitungan keluaran alternator berupa tegangan dan daya. Kemudian dilakukan analisis perbandingan antara hasil pengukuran dalam proses pengujian secara percobaan dengan hasil perhitungan secara teoritis untuk melihat selisih penyimpangannya. Kemudian dilakukan pula perhitungan efisiensi daya dengan 
membandingkan hasil pengukuran daya output alternator dengan daya output dari motor penggerak.

\section{HASIL DAN DISKUSI}

\section{A. Analisis Data}

Data spesifikasi alat yang digunakan pada berdasarkan data yang sudah didapat penelitian studi yaitu:

Tabel 2.

Data Spesifikasi Alat yang dibuat

\begin{tabular}{ccc}
\hline \hline No & Keterangan & Ukuran \\
\hline 1 & Jumlah lilitan & 130 \\
2 & Panjang koil & $5 \mathrm{~cm}$ \\
3 & Diameter kawat & $1,6 \mathrm{~mm}$ \\
4 & Jari - jari lilitan dalam & $5 \mathrm{~cm}$ \\
5 & Jari - jari lilitan terluar & $7 \mathrm{~cm}$ \\
\hline \hline
\end{tabular}

Tabel 3.

Data Spesifikasi Motor Penggerak

\begin{tabular}{ccc}
\hline \hline No & Keterangan & Ukuran \\
\hline 1 & Jari -jari & $30 \mathrm{~cm}$ \\
2 & Berat & $35 \mathrm{~N}$ \\
3 & RPM nominal & 360 \\
4 & Arus & $5 \mathrm{~A}$ \\
5 & Tegangan & $12 \mathrm{~V}$ \\
\hline \hline
\end{tabular}

B. Analisis Perbandingan Tegangan Alternator.

Tabel 4.

Hasil Perbandingan Tegangan Alternator dengan 3 koil

\begin{tabular}{ccccc}
\hline \hline No & RPM & $\begin{array}{c}\text { Tegangan } \\
\text { Pengukuran (Vukur) }\end{array}$ & $\begin{array}{c}\text { Tegangan teoritis } \\
\text { (V teoritis) }\end{array}$ & $\begin{array}{c}\text { Deviasi } \\
(\%)\end{array}$ \\
\hline 1 & 360 & 5.8 & 7,822 & 25,85 \\
2 & 482 & 6 & 10,473 & 42,71 \\
3 & 482.7 & 6.3 & 10,488 & 39,93 \\
4 & 485.1 & 6.6 & 10,540 & 37,38 \\
5 & 485.3 & 6.7 & 10,545 & 36,46 \\
6 & 485.9 & 6.9 & 10,558 & 34,65 \\
\hline \hline
\end{tabular}

Tabel 5 .

Hasil Perbandingan Tegangan Alternator dengan 6 koil

\begin{tabular}{ccccc}
\hline \hline No & RPM & $\begin{array}{c}\text { Tegangan Pengukuran } \\
\text { (Vukur) }\end{array}$ & $\begin{array}{c}\text { Tegangan teoritis } \\
\text { (V teoritis) }\end{array}$ & $\begin{array}{c}\text { Deviasi } \\
(\%)\end{array}$ \\
\hline 1 & 360 & 13,8 & 15,644 & 11,79 \\
2 & 482 & 14,1 & 20,946 & 32,68 \\
3 & 482.7 & 14,4 & 20,977 & 31,35 \\
4 & 485.1 & 14,6 & 21,081 & 30,74 \\
5 & 485.3 & 14,7 & 21,090 & 30,30 \\
6 & 485.9 & 14,9 & 21,116 & 29,44 \\
\hline \hline
\end{tabular}

Perbedaan antara perhitungan dan pengukuran disebabkan adanya rugi - rugi daya sehingga hasil pengukuran lebih kecil dari perhitungan teoritis. Rugi - rugi daya yang hilang ini disebabkan karena panas atau ada yang hilang di fluks magnetik yang tidak semuanya diserap oleh koil atau tidak semua medan magnetiknya bisa dikonversi ke listrik. Setelah penjelasan diatas maka didapatkan hubungan RPM dengan $\mathrm{V}_{\text {input }} 6$ koil dan hubungan RPM dengan $\mathrm{V}_{\text {input }} 3$ koil.

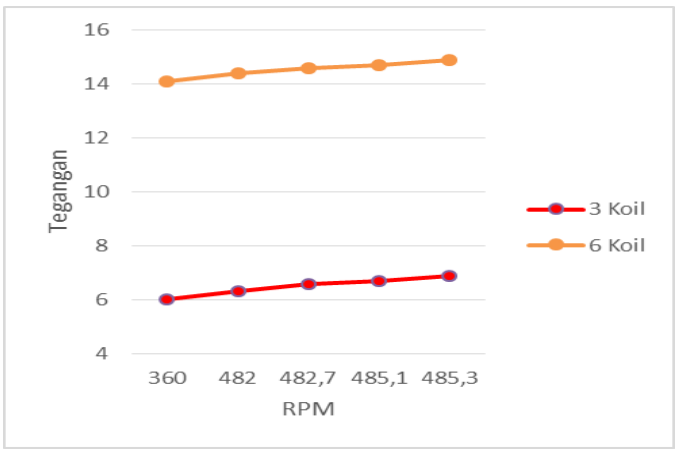

Gambar 9. Grafik Hubungan RPM dengan Tegangan

Berdasarkan hasil yang diperoleh terlihat bahwa grafik antara kecepatan putar (RPM) dengan tegangan berbentuk linier. Dimana semakin besar kecepatan putar (RPM) maka nilai tegangan yang dihasilkan juga semakin besar. Tegangan AC yang dihasilkan kemudian disearahkan menjadi arus searah (DC) menggunakan dioda bridge. Dapat dilihat pula bahwa alternator dengan 6 koil mampu menghasilkan tegangan yang lebih tinggi daripada alternator dengan 3 koil. Maka dapat disimpulkan bahwa semakin tinggi RPM dan semakin banyak koil maka semakin tinggi pula tegangan alternator yang mampu dihasilkan.

\section{Analisis Effisiensi pada alternator}

Untuk mendapatkan effisiensi yang dihasilkan oleh motor adalah digunakan rumus (8) maka :

Tabel 6.

Hasil perhitungan Effisiensi motor untuk 3 koil

\begin{tabular}{ccccccc}
\hline \hline No & RPM & $\begin{array}{c}\text { Daya } \\
\text { Motor } \\
\text { Penggerak } \\
(\mathrm{W})\end{array}$ & $\begin{array}{c}\text { Arus } \\
\text { Alternator } \\
(\mathrm{A})\end{array}$ & $\begin{array}{c}\text { Tegangan } \\
\text { Alternator } \\
(\mathrm{V})\end{array}$ & $\begin{array}{c}\text { Daya } \\
\text { Alternator } \\
(\mathrm{W})\end{array}$ & $\eta(\%)$ \\
\hline 1 & 360 & 60 & 2,5 & 5,8 & 14,5 & 24,167 \\
2 & 482 & 60 & 2,5 & 6 & 15 & 25,000 \\
3 & 482,7 & 60 & 2,5 & 6,3 & 15,75 & 26,250 \\
4 & 485,1 & 60 & 2,5 & 6,6 & 16,5 & 27,500 \\
5 & 485,3 & 60 & 2,5 & 6,7 & 16,75 & 27,917 \\
6 & 485,9 & 60 & 2,5 & 6,9 & 17,25 & 28,750 \\
\hline \hline
\end{tabular}

Tabel 7.

Hasil perhitungan Effisiensi motor untuk 6 koil

\begin{tabular}{ccccccc}
\hline \hline No & RPM & $\begin{array}{c}\text { Daya } \\
\text { Motor } \\
\text { penggerak } \\
(\mathrm{W})\end{array}$ & $\begin{array}{c}\text { Arus } \\
\text { Alternator } \\
(\mathrm{A})\end{array}$ & $\begin{array}{c}\text { Tegangan } \\
\text { Alternator } \\
(\mathrm{V})\end{array}$ & $\begin{array}{c}\text { Daya } \\
\text { Alternator } \\
(\mathrm{W})\end{array}$ & $\eta(\%)$ \\
\hline 1 & 360 & 60 & 2,5 & 13,8 & 34,5 & 57,500 \\
2 & 482 & 60 & 2,5 & 14,1 & 35,25 & 58,750 \\
3 & 482,7 & 60 & 2,5 & 14,4 & 36 & 60,000 \\
4 & 485,1 & 60 & 2,5 & 14,6 & 36,5 & 60,833 \\
5 & 485,3 & 60 & 2,5 & 14,7 & 36,75 & 61,250 \\
6 & 485,9 & 60 & 2,5 & 14,9 & 37,25 & 62,083 \\
\hline \hline
\end{tabular}

Setelah didapatkan hasil perhitungan effsiensi diatas maka dapat digambarkan grafik sebagai berikut : 


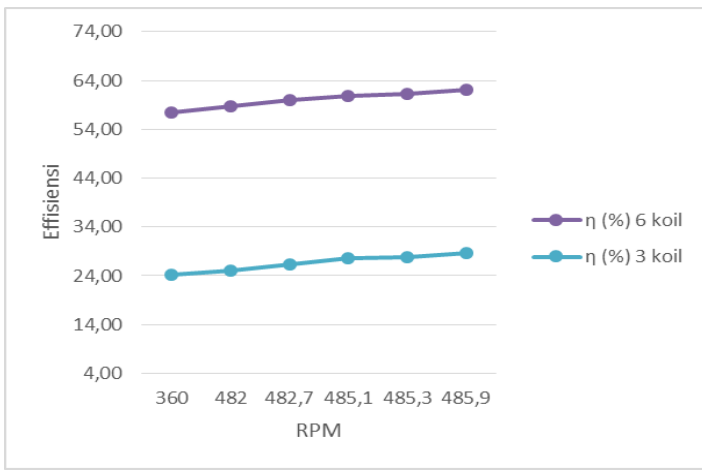

Gambar 10. Grafik Hubungan RPM dengan Effisiensi.

Gambar 10. dapat dilihat bahwa semakin besar RPM maka effisiensi daya alternator semakin tinggi pula . Begitu juga alternator dengan 6 koil memiliki effisiensi yang lebih tinggi dari alternator dengan 3 koil. Maka dapat disimpulkan untuk mempertinggi effisiensi alternator dengan cara mempertinggi RPM dan memperbanyak koil.

\section{KESIMPULAN / RINGKASAN}

Berdasarkan hasil penelitian yang telah dilakukan dapat disimpulkan sebagai berikut:

1.Pembuatan Alternator berbasis magnet permanen Neodymium sebanyak 12 buah pada rotor dan 6 buah pada solenoida. Dimensi rotor dan stator dengan diameter 0,35 meter. Dimensi dari magnet permanen adalah 0,05 meter $\mathrm{x}$ 0,05 meter sedangkan ukuran dari solenoida adalah lingkaran dengan jari - jari dalam 0,05 meter dan jari - jari luar 0,07 meter berisi 130 lilitan kawat imael berdiameter 1,6 milimeter dapat menghasilkan arus rata - rata sebesar 2,5 A dan tegangan rata - rata untuk 3 koil sebesar 5,8 V$6,9 \mathrm{~V}$ sedangkan untuk 6 koil sebesar 13,8 V - 14,9 V.
2. Semakin besar RPM maka efisiensi alternator juga semakin besar sehingga daya output yang dihasilkan juga lebih besar.

3. Dengan Alternator dengan 6 koil memiliki effisiensi yang lebih tinggi dari alternator dengan 3 koil.

\section{DAFTAR PUSTAKA}

[1] B. . Stram, Key Challenges to expanding renewable energy. energy policy, 2016.

[2] A. . Punchstein, A.F., Lioyd, T.C., Conrad, Alternating Current Machines. New York: John Willey and Sons Inc, 1960.

[3] W. Masmoudi, A., Drazikowski, L., Koczara, "Permanent Magnet disk generator with coreless windings," Compel-Int J,COMPUT.Math.Electr. Electron. Eng, pp. 108-118, 2011.

[4] D. C. Giancoli, Physics : principles with applications Sixth Edition. United State of America: Pearson Education, 2005.

[5] R. Tinjo, "Optimasi Jarak Celah Udara Generator Sinkron Magnet Permanen Fluks Aksial Rotor Cakram Ganda Dengan Stator Tanpa Inti," Universitas Indonesia, 2010.

[6] "http://microblog.routed.net/wpcontent/uploads/2008/10/pancakewheel.pdf," 2017. [Online]. Available: http://microblog.routed.net/wpcontent/uploads/2008/10/pancakewheel.pdf.

[7] H. Rudianto, "Penggunaan ICViper 22A Pada Catu Daya Model Penyaklaran Untuk Pemutar Cakram DVD," Universitas Negeri Yogyakarta, 2015.

[8] N. Riedel, Electric Circuit Ninth Editions. New Jersey: Prentice Hall, 2011.

[9] A. Paulus, ““” Pengaruh Tekanan Kompaksi dan waktu Penahanan Temperatur Sintering Terhadap Sifat Magnetik dan kekerasan pada pembuatan Iron Soft Magnetik dari Serbuk Besi," Institut Teknologi Sepuluh Nopember Surabaya, 2007.

[10] K. Faza, "Analisa Variasi Hambatan dan Tengan Listrik pada Koil terhadap Unjuk Kerja Motor Bensin 4 Langkah," Universitas Jember, 2013.

[11] K. et Al, "Pembuatan dan Karakterisasi Magnet Bounded NdFeB dengan Teknik Green Compact," J. Fis. dan Apl., vol. 9, pp. 9-11, 2013.

[12] B. Prasetijo, H., Ropiudin, R., Dharmawan, "Generator Magnet Permanen Sebagai Pembangkit Listrik Putaran Rendah,” Ilm. Din. Rekayasa, vol. 8, pp. 70-77, 2016. 